\title{
Enhanced In Vitro Potency and In Vivo Immunogenicity of a CTL Epitope from Hepatitis C Virus Core Protein following Amino Acid Replacement at Secondary HLA-A2.1 Binding Positions
}

\author{
Pablo Sarobe, ${ }^{\star}$ C. David Pendleton, ${ }^{*}$ Toshitaka Akatsuka, ${ }^{\ddagger}$ Daryl Lau, ${ }^{\S}$ Victor H. Engelhard,, Stephen M. Feinstone, ${ }^{\ddagger}$ \\ and Jay A. Berzofsky* \\ * Molecular Immunogenetics and Vaccine Research Section, Metabolism Branch, National Cancer Institute, National Institutes of Health, \\ Bethesda, Maryland 20892; ${ }^{\ddagger}$ Division of Viral Products, Laboratory of Hepatitis Viruses, Center for Biologics Evaluation and Research, \\ Food and Drug Administration, National Institutes of Health, Bethesda, Maryland 20892; ${ }^{\S}$ Liver Diseases Section, National Institute of \\ Diabetes and Digestive and Kidney Diseases, National Institutes of Health, Bethesda, Maryland 20892; and the ${ }^{\|}$Department of \\ Microbiology, University of Virginia, Charlottesville, Virginia 22908
}

\begin{abstract}
Since the natural immune response to hepatitis $\mathrm{C}$ virus $(\mathrm{HCV})$ is often unable to clear the infection, to enhance immunogenicity we studied substituted peptides from an $\mathrm{HCV}$ cytotoxic T lymphocyte (CTL) epitope (C7A2) from a conserved region of the HCV core protein (DLMGYIPLV) recognized by CTL lines from HLA-A2.1 ${ }^{+} \mathrm{HCV}$-infected patients and HLA-A2.1 transgenic mice. HLA-A2.1 binding, human and murine CTL recognition, and in vivo immunogenicity (using mice transgenic for human HLA-A2 in lieu of immunizing humans) were analyzed to define peptides with enhanced immunogenicity. Peptides substituted at position 1 showed enhanced HLA-A2 binding affinity, but paradoxically poorer immunogenicity. A peptide with Ala substituted at position $8(8 \mathrm{~A})$ showed higher HLA-A2 binding affinity and CTL recognition and was a more potent in vivo immunogen in HLA-A2-transgenic mice, inducing higher CTL responses with higher avidity against native C7A2 than induced by $\mathrm{C} 7 \mathrm{~A} 2$ itself. These results suggest that peptide $8 \mathrm{~A}$ is a more potent in vitro antigen and in vivo immunogen than C7A2 and may be useful as a vaccine component. They provide proof of principle that the strategy of epitope enhancement can enhance immunogenicity of a CTL epitope recognized by human CTL. (J. Clin. Invest. 1998. 102:1239-1248.) Key words: cytotoxic T lymphocyte • epitope enhancement $\cdot$ major histocompatibility complex class I affinity $\bullet$ peptide, synthetic $\cdot$ vaccine
\end{abstract}

P. Sarobe's current address is Departamento de Medicina Interna, Facultad de Medicina, Universidad de Navarra, C/Irunlarrea s/n, 31008 Pamplona, Spain.

Address correspondence to Jay A. Berzofsky, Molecular Immunogenetics and Vaccine Research Section, Metabolism Branch, National Cancer Institute, National Institutes of Health, Building 10, Room 6B12, Bethesda, MD 20892. Phone: 301-496-6874; FAX: 301402-0549; E-mail: berzofsk@helix.nih.gov

Received for publication 14 April 1998 and accepted in revised form 20 July 1998.

J. Clin. Invest.

(C) The American Society for Clinical Investigation, Inc. 0021-9738/98/09/1239/10 \$2.00

Volume 102, Number 6, September 1998, 1239-1248

http://www.jci.org

\section{Introduction}

Hepatitis $\mathrm{C}$ virus $(\mathrm{HCV})^{1}$ is a single-stranded RNA virus responsible for the majority of non-A non-B hepatitis (1). Infection by $\mathrm{HCV}$ frequently evolves to chronicity, and in many cases leads to liver cirrhosis and hepatocellular carcinoma (2). The cellular immune response is thought to be responsible for viral clearance in many viral infections (3-7), and in the case of $\mathrm{HCV}$, a cytotoxic T lymphocyte (CTL) response is present in acutely and chronically infected patients (8-14), but its role in viral clearance has not been elucidated. CTL reponses have been detected in PBMCs and intrahepatic lymphocytic infiltrate in patients with chronic hepatitis (15) and in the liver of infected chimpanzees (16), suggesting that in these cases the virus is able to persist despite this immune response (17). However, the CTL response might contribute to the immunopathogenesis observed during the course of infection. The reasons for the inadequacy of this immune response in chronically infected patients are not known (18), but efforts to improve antiviral mechanisms might lead to improved viral clearance and recovery from infection.

$\mathrm{CD} 8^{+}$CTLs recognize antigens as peptides presented by class I molecules of the major histocompatibility complex (MHC) on the cell surface. These peptides are usually 8-10 amino acids long and are generated after processing of intracellular antigens $(3,19-21)$. Analysis of peptides presented by MHC class I molecules has led to the definition of several sequence patterns or motifs (22-24) for peptides that bind to each particular MHC allele or group of alleles (supermotif) (25). These motifs are based on the presence in precise positions in the peptide sequence of several amino acids (agretopic residues) called anchor residues $(22,26)$, responsible for interactions between peptide and MHC molecules, as well as other secondary positions that may help in stabilizing these interactions (27-29). The use of these motifs to predict peptides able to bind to MHC molecules, together with the development of MHC-peptide binding assays, has led to the characterization of many CTL epitopes in the HCV polyprotein presented by different MHC molecules $(9,10,12,30)$. Among the best studied motifs is that of HLA-A2.1, which is prevalent in a high percentage of the population (31). Several reports describe the

1. Abbreviations used in this paper: CTL, cytotoxic T lymphocyte; CTM, complete T cell medium; FI, fluorescence index; HCV, hepatitis $\mathrm{C}$ virus; IFA, incomplete Freund's adjuvant; MHC, major histocompatibility complex; PBMC, peripheral blood mononuclear cell; TCR, T cell receptor. 
binding motif for this allele, pointing out the importance of anchor as well as secondary residues. Also, MHC binding has been correlated with immunogenicity in different mouse and human systems (30, 32-37).

Despite the presence of the typical anchor residues, a peptide epitope may have different binding ability depending on the other secondary residues. Thus, the presence of some amino acids in secondary positions may enhance or impair its binding ability $(28,38,39)$. However, some other amino acids (epitopic residues) are responsible for recognition by the $\mathrm{T}$ cell receptor (TCR). Thus, $\mathrm{T}$ cell response is triggered by interactions in the trimolecular complex MHC-antigenic peptideTCR, together with some other costimulatory molecules $(40$, 41). These interactions occur between the antigenic peptide and pockets in the structure of both MHC and TCR molecules, and changes in the peptide sequence may affect any of these interfaces. Some of these changes have been described as having a negative effect in the T cell response, by impairing MHC binding or $\mathrm{T}$ cell recognition, but in other cases, replacement of amino acids at certain positions increased the peptide immunogenicity, either due to improvement of MHC binding affinity or $\mathrm{T}$ cell recognition $(32-35,38)$. Thus, our hypothesis is that appropriate modification of the sequence of a peptide epitope can increase the affinity for the MHC molecule without interfering with recognition by the TCR of T cells specific for the natural viral sequence. Therefore, by this process we call epitope enhancement, one should be able to create a more potent vaccine (42-45).

In this report, we analyze the CTL response against C7A2, a conserved peptide epitope from $\mathrm{HCV}$ core protein (amino acids 132-140), presented by HLA-A2.1 class I molecules, and recognized by CTLs from HCV chronically infected individuals $(9,12,30,46)$, implying that this epitope is naturally processed and presented in hepatitis $\mathrm{C}$ infection. This epitope has the typical HLA-A2.1 binding motif, but, despite the presence of $\mathrm{L}$ at position 2 and $\mathrm{V}$ at position 9, has an intermediate binding affinity $(12,30)$. Thus, we analyzed the role of the different peptide residues in HLA-A2.1 binding and TCR recognition to characterize the importance of these positions and the effect of replacement by different amino acids. Changes introduced in secondary HLA-A2.1 binding anchor positions showed that these peptides had a higher binding affinity than $\mathrm{C} 7 \mathrm{~A} 2$, and as a consequence, were more potent than C7A2 for recognition by $\mathrm{C} 7 \mathrm{~A} 2$-specific CTL in most cases, in accordance with previous results reporting that MHC class I binding affinity correlates with peptide potency $(30,32-37)$. Together with in vitro antigenicity, in vivo ability to induce an immune response has been tested with these peptides taking advantage of a transgenic mouse model expressing human HLA-A2.1 molecules $(9,47,48)$ in lieu of immunizing humans. Immunogenicity in this transgenic mouse model has been shown to correlate with antigenicity for human CTL $(9,49)$. In this case, peptide 8A (a peptide wih Ala substituted at position 8) was more immunogenic than native $\mathrm{C} 7 \mathrm{~A} 2$, whereas other peptides with good in vitro recognition did not induce any CTL activity. Peptide 8A-induced CTLs were more effective at lysing C7A2-pulsed cells than the CTLs induced by C7A2 itself. Moreover, CTLs induced in 8A-immunized mice recognized cells pulsed with sequences belonging to other viral genotypes. These results demonstrate that improvement of peptide epitope sequences by replacement of agretopic residues (epitope enhancement) is a good approach to enhance in vitro and in vivo immunogenicity, and suggest that $8 \mathrm{~A}$ is a more effective antigen to increase anti-HCV immune response for immunotherapy or vaccine prophylaxis. This study constitutes the first proof of principle by in vivo immunization that epitope enhancement can improve immunogenicity of a viral CTL epitope recognized by human CTLs.

\section{Methods}

Synthetic peptides. Peptides were prepared in an automated multiple peptide synthesizer (Symphony; Protein Technologies, Inc.) using Fmoc chemistry. They were purified by reverse-phase HPLC, and their sequences were confirmed on an automated sequencer (477A; Applied Biosystems, Foster City, CA).

Cells. The T2 cell line, a gift of Peter Cresswell, is deficient in TAP1 and TAP2 transporter proteins and expresses low levels of HLA-A2.1 (50, 51). The human B lymphoblastoid cell line HMYC1R transfected with HLA-A2.1 (C1R.A2.1) was provided by William Biddison. Cell line C1R.AAD (HMYC1R transfected with the HLA chimeric molecule containing $\alpha 1$ and $\alpha 2$ domains from human HLAA2.1 and $\alpha 3$ from mouse $\mathrm{H}-2 \mathrm{D}^{\mathrm{d}}$ ) has been previously described (48). Cell lines were maintained in complete T cell medium (CTM; 1:1 mixture of RPMI:EHAA; Life Technologies, Grand Island, NY) containing $10 \%$ FBS, $4 \mathrm{mM}$ glutamine, $100 \mathrm{U} / \mathrm{ml}$ penicillin, $100 \mu \mathrm{g} / \mathrm{ml}$ streptomycin, and $50 \mu \mathrm{M} 2$-mercaptoethanol.

Human subjects. PBMCs were isolated from a patient with chronic hepatitis $\mathrm{C}$. The patient had anti-HCV-specific antibodies with the commercially available assay (Ortho Diagnostics, Raritan, $\mathrm{NJ}$ ) and was HCV RNA positive by polymerase chain reaction (PCR).

Mice. Transgenic A2Kb mice (a gift of Linda Sherman, Scripps Research Institute, La Jolla, CA) and transgenic AAD mice, derived from breeders developed at the University of Virginia colony, were bred in our colony at BioCon Inc. (Rockville, MD). These animals have been previously described $(48,52)$ and they express $\alpha 1$ and $\alpha 2$ domains from the human HLA-A2.1 molecule and $\alpha 3$ from mouse $\mathrm{H}-2 \mathrm{~K}^{\mathrm{b}}$ and $\mathrm{H}-2 \mathrm{D}^{\mathrm{d}}$ molecules, respectively.

Binding assays. Peptide binding to HLA molecules was measured using the $\mathrm{T} 2$ mutant cell line according to a protocol previously described (53). T2 cells $\left(3 \times 10^{5} /\right.$ well) were incubated overnight in $96-$ well plates with culture medium (1:1 mixture of RPMI 1640/EHAA containing $2.5 \% \mathrm{FBS}, 100 \mathrm{U} / \mathrm{ml}$ penicillin, $100 \mu \mathrm{g} / \mathrm{ml}$ streptomycin) with $10 \mu \mathrm{g} / \mathrm{ml} \beta 2$-microglobulin (Sigma Chemical Co., St. Louis, MO) and different peptide concentrations. The next day, cells were washed twice with cold PBS containing 2\% FBS and incubated for $30 \mathrm{~min}$ at $4^{\circ} \mathrm{C}$ with anti-HLA-A2.1 BB7.2 mAb (1/80 dilution from hybridoma supernatant) and $5 \mu \mathrm{g} / \mathrm{ml}$ FITC-labeled goat anti-mouse Ig (PharMingen, San Diego, CA). Cells were washed twice after each incubation, and HLA-A2.1 expression was measured by flow cytometry (FACScan; Becton Dickinson, Mountain View, CA). HLA-A2.1 expression was quantified as fluorescence index (FI) according to the formula: $\mathrm{FI}=$ (mean fluorescence with peptide - mean fluorescence without peptide)/mean fluorescence without peptide. Background fluorescence without BB7.2 was subtracted for each individual value. To compare the different peptides, $\mathrm{FI}_{0.5}$, the peptide concentration that increases HLA-A2.1 expression by $50 \%$ over no peptide control background, was calculated from the titration curve for each peptide.

CTL generation in humans. CTL lines were generated according to the protocol previously described $(12,14)$. PBMCs from a patient chronically infected with HCV were separated by Ficoll-Hypaque and $10^{6}$ cells were stimulated in $400 \mu \mathrm{l}$ in 48 -well plates with $2 \times 10^{6}$ autologous cells pulsed previously for $3 \mathrm{~h}$ with $10 \mu \mathrm{M}$ peptide in CTM. After $3 \mathrm{~d}$, the same volume of CTM with IL-2 (10\% vol/vol) was added to each well, and the cells were further expanded on day 6 with IL-2 containing CTM. This cycle was repeated every 10 days. For the first three times, $2 \times 10^{6}$ peptide pulsed irradiated $(3,000$ rads) autologous PBMCs were used as antigen-presenting cells, and 
in subsequent cycles, CTLs were stimulated with $3 \times 10^{5}$ peptide pulsed irradiated (3,000 rads) autologous Concanavalin A (Con A) blasts and $1.5 \times 10^{6}$ irradiated allogeneic PBMCs. Con A blasts were obtained by stimulating PBMCs with $10 \mu \mathrm{g} / \mathrm{ml}$ Con A and expanding with CTM containing $50 \mathrm{U} / \mathrm{ml}$ IL-2 and $1 \mathrm{U} / \mathrm{ml}$ IL-6. Con A blasts were stimulated with Con A every $8-10$ days.

CTL generation in mice. 8- to 12 -wk-old mice were immunized subcutaneously in the base of the tail with $100 \mu \mathrm{l}$ of an emulsion containing 1:1 incomplete Freund's adjuvant (IFA) and PBS solution with antigens and cytokines (50 $\mathrm{nmol} \mathrm{CTL}$ epitope, $50 \mathrm{nmol} \mathrm{HBV}$ core 128-140 helper epitope, $3 \mu \mathrm{g}$ of IL-12, and $3 \mu \mathrm{g}$ of granulocyte macrophage colony stimulating factor) (54). Mice were boosted $2 \mathrm{wk}$ later, and spleens removed 10-14 d after the boost. Immune spleen cells $\left(2.5 \times 10^{6} /\right.$ well $)$ were stimulated in 24 -well plates with autologous spleen cells $\left(5 \times 10^{6} /\right.$ well $)$ pulsed for $2 \mathrm{~h}$ with $10 \mu \mathrm{M}$ CTL epitope peptide in CTM with $10 \%$ T-Stim (Collaborative Biomedical Products, Bedford, MA). After two in vitro stimulations with peptide-pulsed syngeneic spleen cells, CTL lines were maintained by weekly restimulation of $10^{6} \mathrm{CTL} /$ well with $2 \times 10^{5}$ peptide pulsed irradiated $(10,000$ rads $) \mathrm{C} 1 \mathrm{R}$.AAD cells and $4 \times 10^{6} \mathrm{C} 57 / \mathrm{B} 16$ irradiated (3,000 rads) spleen cells as feeders.

Cytotoxicity assay. CTL activity was measured using a 4-h assay with ${ }^{51} \mathrm{Cr}$-labeled target cells. Target cells $\left(10^{6}\right)$ were pulsed in $100 \mu \mathrm{l}$ CTM with or without $10 \mu \mathrm{M}$ peptide and $150 \mu \mathrm{Ci}^{51} \mathrm{Cr}$ for $2 \mathrm{~h}$, washed three times, and added to the plates containing different number of effector cells in a final volume of $200 \mu \mathrm{l}$. In peptide titration assays, target cells were pulsed with ${ }^{51} \mathrm{Cr}$ for $2 \mathrm{~h}$, washed three times, and added to the plates with different peptide concentrations. Effector cells were added $2 \mathrm{~h}$ later, and the supernatants were harvested and counted after an additional $4 \mathrm{~h}$ of incubation. The percentage of specific ${ }^{51} \mathrm{Cr}$ release was calculated as: $100 \times($ experimental release spontaneous release)/(maximum release - spontaneous release). Spontaneous release was determined from target cells incubated without effector cells, and maximum release was determined in the presence of $5 \%$ Triton X-100. C1R.A2.1 and C1R.AAD lines and $\mathrm{AAD}$ and $\mathrm{A} 2 \mathrm{~Kb}$ Con A blasts were used as targets. Con A blasts were prepared by culturing $3 \times 10^{6}$ spleen cells in $2 \mathrm{ml}$ of CTM in the presence of $2 \mu \mathrm{g} / \mathrm{ml}$ of Con A in 24-well culture plates. After 2 days, cells were harvested and processed for labeling as described.

\section{Results}

C7A2 Ala-substituted peptides binding to HLA-A2.1 molecules. A first approach to enhance peptide immunogenicity is to improve the affinity of CTL epitopes for HLA class I molecules $(34,35)$. For this reason, we decided to focus on a peptide from a conserved region from the $\mathrm{HCV}$ core protein (amino acids 132-140) designated C7A2, previously described as a CTL epitope by ourselves and others $(8,10)$. This epitope is endogenously processed and presented and recognized by HLA-A2.1-restricted CTL in HCV-infected patients (9, 10, $12)$, induces in vitro primary responses in normal donors (37, 55), is immunogenic in HLA-A2.1 expressing transgenic mice $(9,37)$, and has been described as a binder with intermediate affinity to HLA-A2.1 molecules $(12,30)$. This intermediate binding affinity allowed us to introduce modifications aimed at improving binding, compared with other HCV epitopes described as high affinity binders and more difficult to improve. It is also relatively conserved, with only a few conservative substitutions reported $(56,57)$. Such a conserved epitope may be more valuable in a vaccine than a higher affinity one that is more variable.

We evaluated the binding affinity of wild-type C7A2 (C7A2-WT) with a T2 binding assay (53), measuring the cell surface stabilization of HLA-A2.1 molecules after incubation with peptide. To compare the different peptides, $\mathrm{FI}_{0.5}$ was chosen as a way to compare titrations of the peptides and relative affinity for MHC molecules. Using this method, $\mathrm{FI}_{0.5}$ of $10 \mu \mathrm{M}$ was calculated for C7A2-WT.

In a first set of experiments to define key functional residues, peptides with alanine substitutions at each one of the positions were synthesized and tested in binding assays (Table I). C7A2-WT has the typical motif for binding to HLA-A2.1, with $\mathrm{L}$ and $\mathrm{V}$ at positions 2 and 9, respectively $(22,23)$. Thus, substitutions at these positions would eliminate binding, but also substitutions in other positions might tell us the importance of other secondary residues. Binding experiments with these alanine-substituted peptides showed (Fig. $1 a$ ) that peptide $2 \mathrm{~A}$ had lost binding ability, in accordance with the anchor character of this position, and also 9A had impaired binding, although not as much as $2 \mathrm{~A}$, since Ala can function as a weak anchor at position 9. Other substitutions that decreased binding were $6 \mathrm{~A}$ and $7 \mathrm{~A}$, suggesting the importance of these residues as secondary anchor positions. However, peptides 4A and $8 \mathrm{~A}$ had higher affinity, with $\mathrm{FI}_{0.5}$ around $2 \mu \mathrm{M}$. Finally, substitutions at positions 1,3 , and 5 did not have any effect on peptide binding.

Binding of peptides with substitutions at position 1. C7A2WT has aspartic acid, a negatively charged residue, in position 1 , that according to previously reported data (28) has been described as a residue with a negative effect on binding to HLAA2.1. This character made this position potentially amenable to changes to improve the binding ability. Substitution by Ala at this position, although replacing the charged residue, did not improve binding, so the original $\mathrm{D}$ was replaced by other residues described as having a positive effect at this position (28). Peptides with aromatic amino acids at this position $(\mathrm{F}$ and $\mathrm{H})$, as well as $\mathrm{N}$ (which eliminates the negative charge but keeps the size), or $\mathrm{S}$ and $\mathrm{T}$, small polar amino acids that can hydrogen bond, were synthesized.

As shown in Fig. $1 \mathrm{~b}$, peptides $1 \mathrm{~N}, 1 \mathrm{H}$, and $1 \mathrm{~T}$ had improved binding affinity, whereas $1 \mathrm{~F}$ (although $\mathrm{F}$ has been described at this position in many HLA-A2.1 binders) had a $\mathrm{FI}_{0.5}$ higher than C7A2-WT, indicating lower affinity. Solubility problems with $1 \mathrm{~F}$ may account for impaired binding ability in this case.

Table I. Sequence of the Peptides Used in the Present Study

\begin{tabular}{lccc}
\hline \multicolumn{1}{c}{ Peptide } & Sequence & Peptide & Sequence \\
\hline C7A2-WT & DLMGYIPLV & $1 \mathrm{~N}$ & NLMGYIPLV \\
1A & ALMGYIPLV & $1 \mathrm{~F}$ & FLMGYIPLV \\
2A & DAMGYIPLV & $1 \mathrm{H}$ & HLMGYIPLV \\
$3 \mathrm{~A}$ & DLAGYIPLV & $1 \mathrm{~S}$ & SLMGYIPLV \\
4A & DLMAYIPLV & $1 \mathrm{~T}$ & TLMGYIPLV \\
$5 \mathrm{~A}$ & DLMGAIPLV & $3 \mathrm{I}$ & DLIGYIPLV \\
$6 \mathrm{~A}$ & DLMGYAPLV & $3 \mathrm{~L}$ & DLLGYIPLV \\
$7 \mathrm{~A}$ & DLMGYIALV & $3 \mathrm{~V}$ & DLVGYIPLV \\
$8 \mathrm{~A}$ & DLMGYIPAV & $3 \mathrm{~K}$ & DLKGYIPLV \\
$9 \mathrm{~A}$ & DLMGYIPLA & $3 \mathrm{~W}$ & DLWGYIPLV \\
& & $7 \mathrm{G}$ & DLMGYIGLV \\
& & $7 \mathrm{~V}$ & DLMGYIVLV \\
& & $8 \mathrm{~V}$ & DLMGYIPVV \\
& & $9 \mathrm{~S}$ & DLMGYIPLS
\end{tabular}



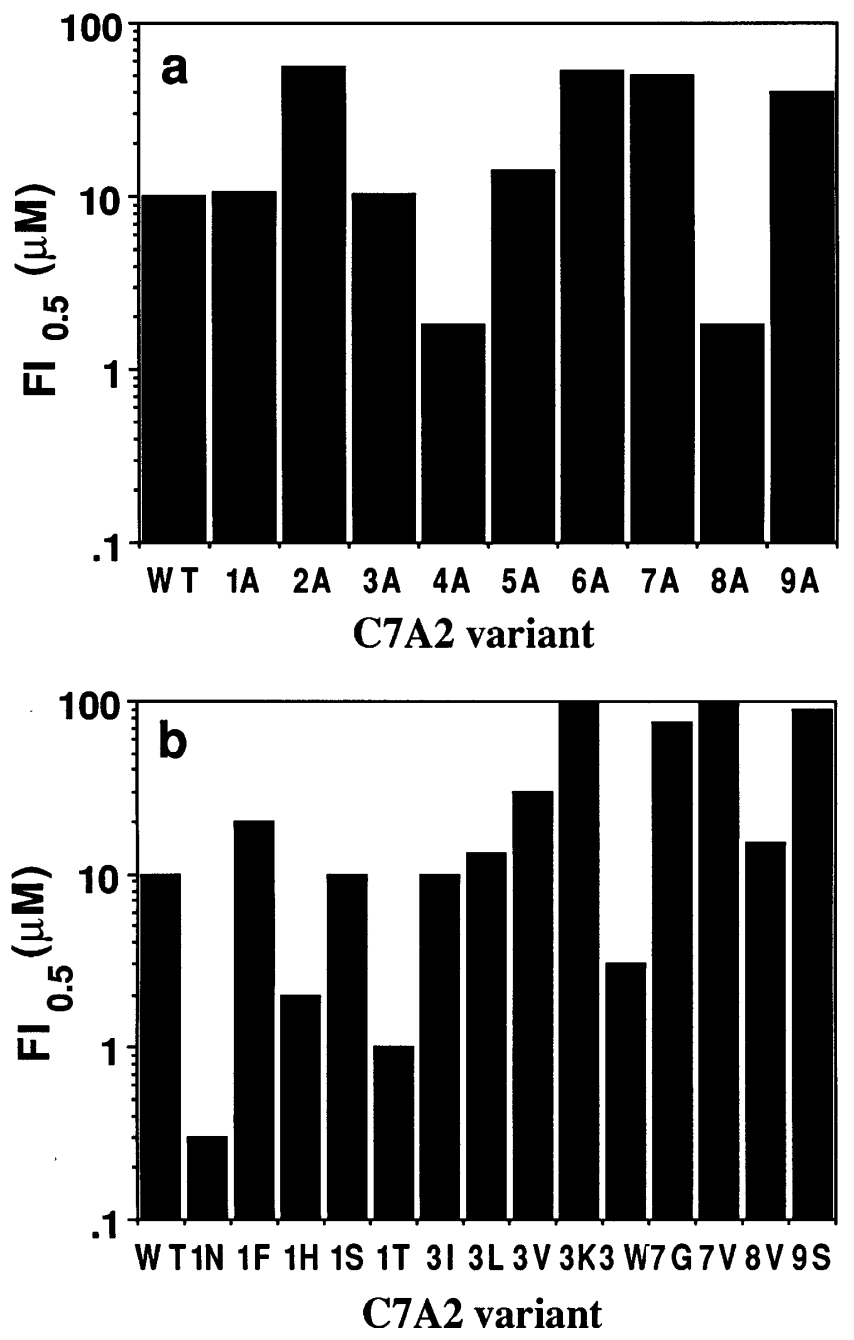

Figure 1. Binding of C7A2 (a) Alanine and $(b)$ non-Alanine-substituted peptides to HLA-A2.1. T2 cells were incubated overnight in a 96-well plate in CTM with $10 \mu \mathrm{g} / \mathrm{ml}$ human $\beta 2$-microglobulin and different peptide concentrations. Next day cells were washed, and HLA-A2.1 expression was assessed by flow cytometry using the antiHLA-A2 BB7.2 mAb and FITC-labeled goat anti-mouse Ig. Results are expressed as fluorescence index (FI), calculated according to the formula: (mean fluorescence with peptide - mean fluorescence without peptide)/mean fluorescence without peptide. Background fluorescence without $\mathrm{BB} 7.2$ was subtracted for each individual value. $\mathrm{FI}_{0.5}$ represents those peptide concentrations that increase HLA-A2.1 expression by $50 \%$ over the no peptide control, and values were calculated from the titration curves for each particular peptide.

Binding of peptides with substitutions at other positions. Substitution by A at position 7 yielded a peptide with impaired binding ability. The natural amino acid at this position is $\mathrm{P}$, which is known to induce turns in peptide chains. To discriminate whether the A replacement changed the structure of the peptide chain or eliminated the side chain responsible for interaction with HLA-A2.1, we synthesized 7G, an amino acid that also contributes to $\beta$ turns as does $\mathrm{P}$, but lacks the side chain, and $7 \mathrm{~V}$, with an aliphatic side chain bulkier than A. None of these peptides bound to HLA-A2.1 (Fig. $1 b$ ), suggesting a specific role of the $\mathrm{P}$ side chain in the binding to HLA-A2.1.
Position 3 was replaced by $\mathrm{W}$, because $\mathrm{W}$ is frequently found at this position in HLA-A2.1-binding peptides (28), and by $\mathrm{K}, \mathrm{L}, \mathrm{I}$, and V, charged and aliphatic residues. Binding was improved with $3 \mathrm{~W}$ (Fig. $1 \mathrm{~b}$ ), but it was completely abolished in $3 \mathrm{~K}$. Peptide $3 \mathrm{~V}$ had impaired binding, whereas $3 \mathrm{~L}$ and $3 \mathrm{I}$ were similar to C7A2-WT.

Finally, it was of interest to replace position $8 \mathrm{~L}$ with a $\mathrm{V}$, an aliphatic residue similar to $\mathrm{A}$ and $\mathrm{L}$ (amino acid present in C7A2-WT), but with an intermediate size between them. Moreover, $8 \mathrm{~V}$ is one of the few sequence variations that can be found within this epitope and is common in viral isolates belonging to $\mathrm{HCV}$ genotypes $2 \mathrm{a}$ and $2 \mathrm{~b}(56,57)$. Peptide $8 \mathrm{~V}$ had an $\mathrm{FI}_{0.5}$ of $15 \mu \mathrm{M}$, in the range of C7A2-WT.

Recognition of C7A2-variant peptides by human CTLs. To determine residues involved in CTL recognition, a CTL line specific for C7A2 was established from PBMCs from an HCV-infected patient after several rounds of C7A2-WT peptide stimulation. Lytic activity of these CTLs was tested with target cells incubated with different concentrations of each one of the peptides to study the recognition of the different variants and titrate the T cell avidity. In the case of Ala-substituted peptides (Fig. $2 a$ ), 2A and 9A were not recognized, in accordance with the anchor character of these positions. Also, 3A was not recognized, despite good HLA-A2.1 binding, suggesting the epitopic character of this position. Peptides 4A, 5A, $6 \mathrm{~A}$, and $7 \mathrm{~A}$, although recognized at the highest concentrations, showed poorer recognition than C7A2-WT, as a consequence in some cases of poorer MHC binding (6A and 7A) or
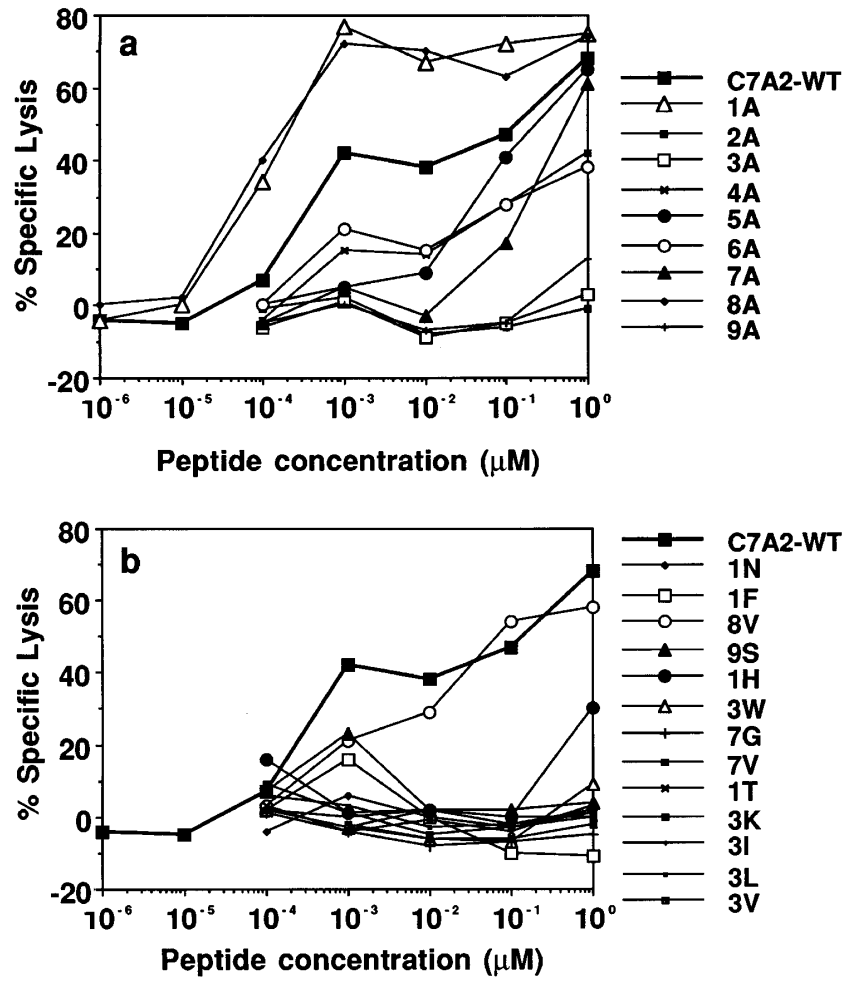

Figure 2. Recognition of C7A2 (a) Alanine and (b) non-Alaninesubstituted peptides by human CTL line ViT2. C1R.A2.1 target cells were incubated for $2 \mathrm{~h}$ with ${ }^{51} \mathrm{Cr}$, washed three times, and plated at 3,000 cells/well in 96-well round-bottom plates with different peptide concentrations. After $2 \mathrm{~h}$, effector cells were added (E/T ratio, 5:1), and the plates were incubated for $4 \mathrm{~h}$. 
otherwise of impaired T-cell recognition (4A and 5A). Finally, $1 \mathrm{~A}$ and $8 \mathrm{~A}$ showed higher levels of lysis than C7A2-WT, and titrated at 10 -fold lower concentrations.

In the case of the non-Ala substituted peptides (Fig. $2 b$ ), none of them was recognized by the CTL at the concentrations tested (including those having high binding affinity, such as $1 \mathrm{~N}$ or $1 \mathrm{~T}$ ), with the exception of $8 \mathrm{~V}$, which behaved similarly to C7A2-WT, and $1 \mathrm{H}$, which induced marginal lysis at the highest concentration tested.

Recognition of C7A2-variant peptides by HLA-A2.1 transgenic mouse CTL. AAD transgenic mice express $\alpha 1$ and $\alpha 2$ domains from the human HLA-A2.1 molecule and $\alpha 3$ from the mouse $\mathrm{D}^{\mathrm{d}}$ molecule (48). Transgenic mice expressing human HLA-A2.1 molecules have been described as a model of presentation and recognition of several HLA-A2.1-restricted antigens $(9,37,47,58-60)$, and allow testing of immunogenicity in the context of a human HLA molecule prior to immunizing humans. To use our antigen in this model, recognition of the different C7A2 variants by murine CTLs in vitro should be studied prior to testing the immunogenicity of the different peptides in vivo.

CTL lines AAD.10 and AAD.1 were induced by immunization with peptide C7A2-WT together with a helper epitope presented by the $\mathrm{H}-2^{\mathrm{b}}$ class II MHC molecules of this strain and GM-CSF and IL-12 according to the method of Ahlers et al. (54). After 10-12 in vitro stimulations with C7A2-WT, these lines were tested against the whole panel of C7A2-substituted peptides in a lytic assay to compare the recognition of the different peptides with that by the human CTL line. In the case of the Ala-substituted peptides (Fig. 3, $a$ and $c$ ), 1A and $8 \mathrm{~A}$ were able to sensitize target cells in a concentration range around that of C7A2-WT, 1A being more effective than $8 \mathrm{~A}$ for both lines. The other peptides titrated at several 10 -fold concentrations higher. Peptides $5 \mathrm{~A}, 7 \mathrm{~A}$, and $2 \mathrm{~A}$ required the
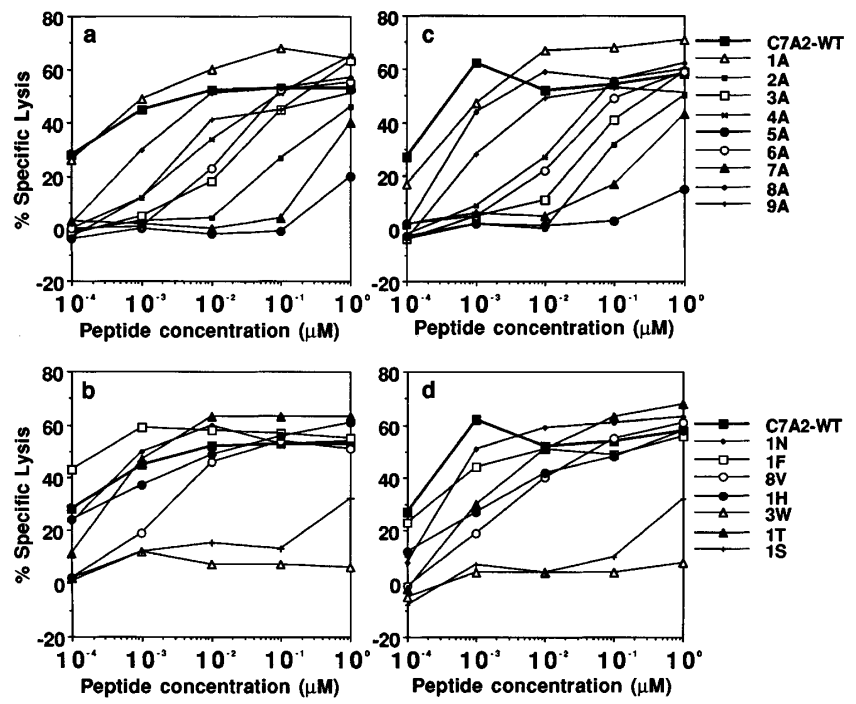

Figure 3. Recognition of C7A2 ( $a$ and $c$ ) Alanine and ( $b$ and $d$ ) nonAlanine-substituted peptides by transgenic AAD mouse CTL lines AAD.10 ( $a$ and $b$ ) and AAD.1 ( $c$ and $d$ ) after 10-12 in vitro stimulations. C1R.AAD target cells were incubated for $2 \mathrm{~h}$ with ${ }^{51} \mathrm{Cr}$, washed three times, and plated at 3,000 cells/well in 96-well round-bottom plates with different peptide concentrations. After $2 \mathrm{~h}$, effector cells were added (E/T ratio, 10:1), and the plates were incubated for $4 \mathrm{~h}$. highest concentrations to induce significant lysis, whereas $3 \mathrm{~A}$, $6 \mathrm{~A}, 4 \mathrm{~A}$, and 9A titrated at intermediate concentrations. These results confirm that substitutions at agretopic positions as 2 and 7 decrease binding to HLA-A2.1 and almost abrogate CTL recognition. However, position 5 was clearly shown to be an epitopic residue, and almost no significant lysis was obtained with target cells sensitized with peptide $5 \mathrm{~A}$, as had been observed for position 3 in the human CTL line. Peptide 3A titrated at a lower concentration, suggesting that in the case of the murine HLA-A2.1-restricted CTL lines, position 3 is not involved in TCR binding as clearly as in the human line. Finally, peptides with subtitutions at positions 4 and 6 were recognized as in the case of the human CTL line.

Together with Ala-substituted peptides, peptides with substitutions by other amino acids and positive binding to HLAA2.1 were also tested in recognition by AAD mouse CTL lines (Fig. 3, $b$ and $d$ ). These peptides mainly contained substitutions at position 1, except for peptides $8 \mathrm{~V}$ and $3 \mathrm{~W}$. Surprisingly, with the exception of $1 \mathrm{~S}$, which required a high peptide concentration to sensitize target cells, all the peptides with substitutions at position 1 were recognized by AAD mouse CTL lines in a concentration range around C7A2-WT, and in some cases, like $1 \mathrm{~F}$, induced a higher response with line AAD.10. Peptide 8V was recognized at higher concentrations than C7A2-WT, whereas peptide $3 \mathrm{~W}$ was not recognized at any of the concentrations tested.

In vivo immunogenicity of C7A2-derived peptides in HLAA2.1 transgenic mice. After studying the recognition of C7A2derived peptides by human and AAD transgenic murine CTL, we tested the in vivo immunogenicity of these peptides in the AAD transgenic mouse model. Different groups of animals were immunized with the substituted CTL epitopes in conjunction with a helper epitope and cytokines as above, and their ability to induce an immune response was tested in CTL assays. In these assays were included some of the peptides with positive binding that were recognized by AAD mouse CTL lines. As shown in Fig. 4, peptides C7A2-WT and 8A were able to induce clear CTL responses, whereas $1 \mathrm{~A}$ could induce only a marginal response. In contrast, peptides $1 \mathrm{~N}$ and $1 \mathrm{~F}$ were unable to induce any measurable CTL response.

Induction of CTL immune response against C7A2-WT by C7A2-WT and $8 A$ peptides in HLA-A2.1 transgenic mice. Among all the peptides tested in binding assays to HLA-A2.1 and recognition by human and transgenic mice CTL, 8A was the most promising. This peptide was able to bind at lower concentrations than C7A2-WT, sensitized human and mouse target cells in the same range or even at lower concentrations than C7A2-WT, and, in immunization experiments, induced higher levels of lysis. Therefore, the ability of 8A to induce a CTL immune response against C7A2-WT was tested in the next set of experiments. In a first experiment, each peptide was used to immunize two groups of animals, with 50 or $15 \mathrm{nmol}$ of CTL epitope peptide as described in Methods. After two immunizations, spleen cells were stimulated in vitro with the same peptide used for immunization, and the lytic activity against C7A2-WT (and 8A in the groups immunized with 8A) was tested. As shown in Fig. 5, two of the four animals immunized with C7A2-WT were able to respond to this peptide, whereas in the animals immunized with $8 \mathrm{~A}$, together with positive responses to $8 \mathrm{~A}$ itself, strong responses to $\mathrm{C} 7 \mathrm{~A} 2-\mathrm{WT}$ could be detected, even in the group of mice immunized with $15 \mathrm{nmol}$. 


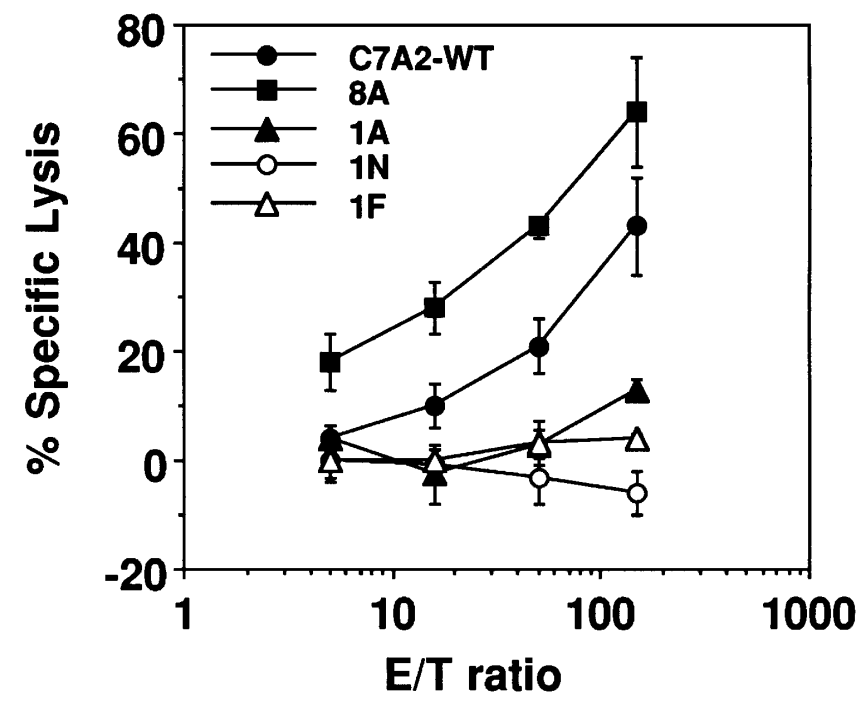

Figure 4. Immunogenicity of C7A2-substituted peptides in AAD transgenic mice. Mice were immunized with $50 \mathrm{nmol}$ CTL epitope plus $50 \mathrm{nmol} \mathrm{HBVc} \mathrm{128-140} \mathrm{helper} \mathrm{epitope} \mathrm{and} \mathrm{GM-CSF} \mathrm{and} \mathrm{IL-12}$ in IFA. 2 wk later, they were boosted, and 10-14 d after the boost, spleen cells were removed and stimulated in vitro with the CTL epitope. After $1 \mathrm{wk}$ of in vitro stimulation, CTL assay was performed with target cells (AAD Con A blasts) incubated with or without $10 \mu \mathrm{M}$ CTL peptide. CTL from each group were tested only with the peptide used to immunize those mice. Only the results for peptide-pulsed target cells are shown. In all the cases, percentages of specific lysis against peptide unpulsed target cells were below $5 \%$.

In a second group of experiments, $\mathrm{A} 2 \mathrm{~Kb}$ transgenic mice, that express also a chimeric HLA molecule with $\alpha 1$ and $\alpha 2$ domains from human HLA-A2.1 and $\alpha 3$ from mouse $\mathrm{K}^{\mathrm{b}}$, were immunized with $50 \mathrm{nmol}$ C7A2-WT or $8 \mathrm{~A}$, and the ability of these peptides to induce a CTL response recognizing C7A2WT was tested. Thus, we could test immunogenicity in a different model system. Figure 6 shows that, as in the case of the AAD mice, C7A2-WT induced a low response, whereas the immunization with 8A induced a higher level of CTL that recognized both C7A2-WT and 8A, even using a lower E/T ratio in the CTL assay (70:1 vs. 120:1).

CTL avidity for their target peptide-MHC complex, defined as the sensitivity to detect low densities of peptide-MHC complex on the surface of target or stimulator cells, has been shown to make a substantial difference in the ability of CTL to clear a virus infection in vivo, in two murine model systems $(61,62)$. Therefore, to determine whether the CTLs raised against the modified peptide $8 \mathrm{~A}$ were of as high avidity against targets presenting the wild-type peptide as would be CTLs raised against the wild-type peptide itself, we titrated C7A2WT on target cells and compared the killing by short-term lines raised against this peptide or against 8A (Fig. 7). The CTLs raised against 8A killed targets expressing the C7A2WT at concentrations more than 100-fold lower than were required to get comparable levels of killing by the CTL raised against the C7A2-WT itself. Thus, use of the modified peptide in this case increases not only immunogenicity but also the avidity of the CTLs that are produced, an additional advantage for the potential efficacy of a vaccine.

Recognition of peptide $8 \mathrm{~V}$ by CTLs from $8 \mathrm{~A}$ immunized HLA-A2.1 transgenic mice. As mentioned above, one of the
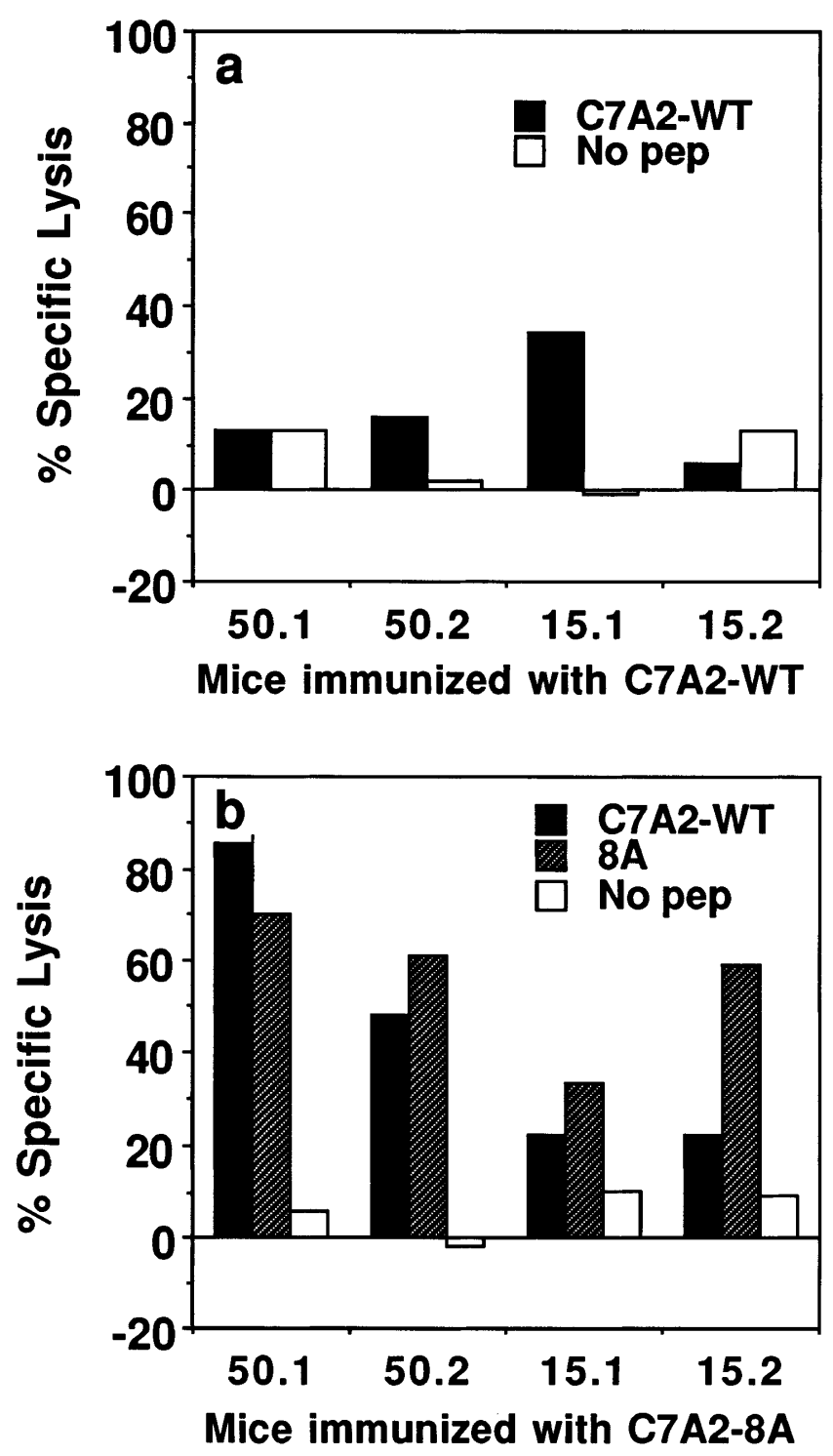

Figure 5. Induction of CTL immune response against C7A2-WT in AAD transgenic mice using different C7A2 peptide variants. Mice were immunized with 50 or $15 \mathrm{nmol}$ CTL epitope C7A2-WT $(a)$ or 8A (b) plus $50 \mathrm{nmol} \mathrm{HBVc} 128-140$ helper epitope and GM-CSF and IL-12 in IFA. 2 wk later, they were boosted under the same conditions, and 10-14 d after the boost, spleen cells were removed and stimulated in vitro with $10 \mu \mathrm{M}$ CTL peptide-pulsed spleen cells. After 2 wk of in vitro stimulation, CTL assay was performed with target cells (AAD Con A blasts) incubated with or without $10 \mu \mathrm{M}$ peptide. 50.1 and 50.2 , and 15.1 and 15.2 designate different mice immunized with 50 or $15 \mathrm{nmol}$ CTL epitope, respectively (E/T ratio in the assay, 90:1).

peptides that is recognized by both human and mouse C7A2WT-specific CTL lines is peptide $8 \mathrm{~V}$. This peptide is common in viral isolates from HCV genotypes $2 a$ and $2 b(56,57)$. Since $8 \mathrm{~A}$ has a change in the same position, it was an interesting point to know if CTLs induced by immunization with $8 \mathrm{~A}$ were cross-reactive not only with C7A2-WT, which corresponds to viral sequences from genotypes $1 \mathrm{a}, 1 \mathrm{~b}$, and $3 \mathrm{a}$, but also with peptide $8 \mathrm{~V}$, belonging to viral sequences from genotype 2 . Results in Fig. 8 show that CTLs induced by immunization with $8 \mathrm{~A}$ recognize peptide $8 \mathrm{~V}$ both in $\mathrm{AAD}$ and in $\mathrm{A} 2 \mathrm{~Kb}$ mice in a way similar to the recognition of C7A2-WT. 


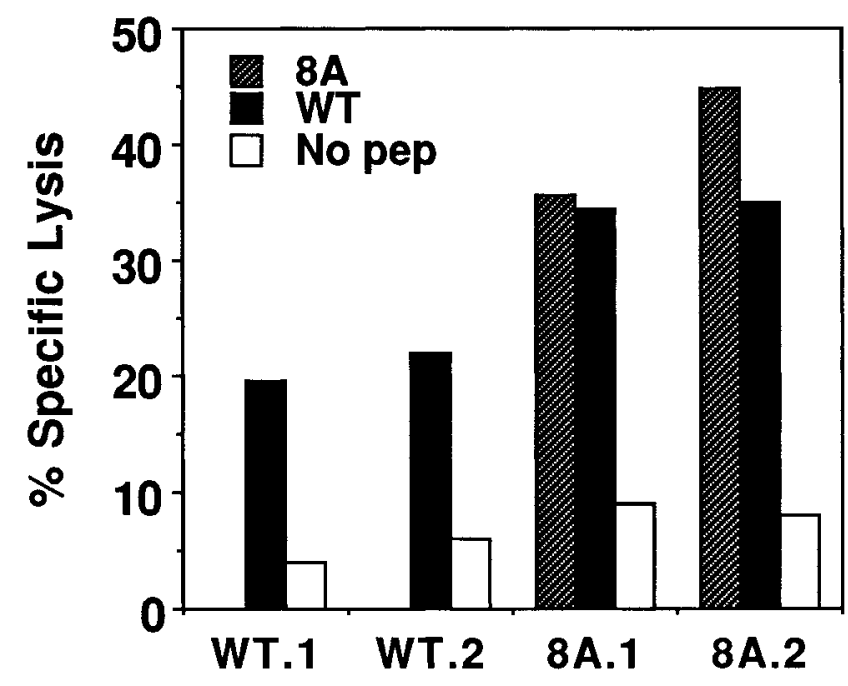

Figure 6. Induction of CTL immune response against C7A2-WT in $\mathrm{A} 2 \mathrm{~Kb}$ transgenic mice using different $\mathrm{C} 7 \mathrm{~A} 2$ peptide variants. Mice were immunized with $50 \mathrm{nmol}$ CTL epitope C7A2-WT or 8A plus 50 nmol HBVc 128-140 helper epitope in IFA. 2 wk later, they were boosted under the same conditions, and 10-14 d after the boost, spleen cells were removed and stimulated in vitro with $10 \mu \mathrm{M}$ CTL peptide-pulsed spleen cells. After 2 wk of in vitro stimulation, CTL assay was performed with target cells (A2Kb Con A blasts) incubated with or without $10 \mu \mathrm{M}$ peptide. WT.1 and WT.2, and 8A.1 and 8A.2 designate different mice immunized with C7A2-WT and 8A CTL epitope, respectively (E/T ratio in the assay, 120:1 for WT.1 and WT.2, 70:1 for 8 A.1 and 8A.2).

\section{Discussion}

A CTL response in HCV infection is found in PBMCs (8-14) and in the liver of patients and infected chimpanzees $(15,16)$, but despite the importance of CTLs in the clearance of virus in many infections, in the case of $\mathrm{HCV}$, the CTL response does not seem to be adequate to achieve complete recovery (17). Improvement of epitopes recognized in the natural infection might lead to an enhancement of the antiviral immune response, and ultimately, together with other effector arms of the immune system, might help in viral clearance.

For several years, our lab has focused on an "epitope enhancement" approach to making vaccines that can be more effective than the natural virus at inducing $\mathrm{T}$ cell responses (38, $42-45,63)$. By modifying the sequence of an epitope to increase affinity for the MHC molecule without altering what the $\mathrm{T}$ cell sees, one can potentially make a more potent immunogen capable of inducing $T$ cells specific for the natural viral sequence. Most of our experience so far is with helper $\mathrm{T}$ cells and binding to class II MHC molecules, but we hypothesize that the same approach could be applied to class I MHC molecules presenting to CTLs. Indeed, a few examples of improved binding to class I MHC molecules have been reported $(34,35)$.

In this report, the CTL response against modified peptides from a HCV HLA-A2.1 restricted epitope has been analyzed. This epitope has an intermediate HLA binding affinity (12, $30)$, is recognized by CTLs from HCV-infected patients $(9,10$, 12), and induces CTL responses in transgenic mice bearing HLA-A2.1 molecules $(9,37)$. In a first approach, HLA-A2.1 binding studies with Ala-substituted peptides showed the role of each residue. Thus, as expected by the presence of $\mathrm{L}$ at posi-

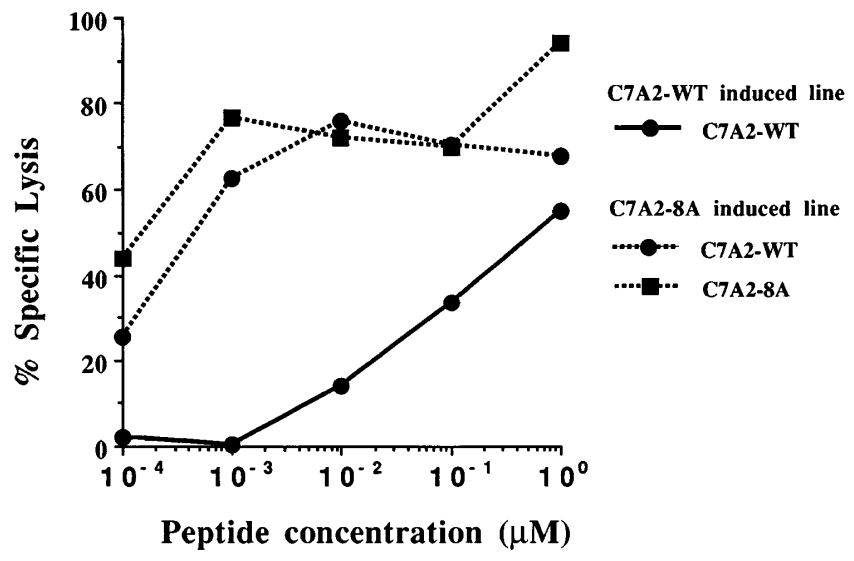

Figure 7. Avidity of short-term CTL lines induced with C7A2-WT and C7A2-8A. AAD transgenic mice were immunized as described in the Methods with $50 \mathrm{nmol}$ CTL epitope C7A2-WT (solid lines) or C7A2-8A (dotted lines) plus 50 nmol HBVc 128-140 helper epitope and GM-CSF and IL-12 in IFA. 2 wk later, they were boosted under the same conditions, and 10-14 d after the boost, spleen cells were removed and stimulated in vitro with $10 \mu \mathrm{M}$ CTL peptide-pulsed spleen cells. After three to four in vitro stimulation cycles, the CTL assay was performed with target cells (C1R.AAD) incubated with different peptide concentrations as indicated (circles, targets with C7A2-WT peptide; squares, targets with C7A2-8A peptide), at an E/T ratio of 10:1.

tion 2 and $\mathrm{V}$ at position 9, these amino acids behaved as anchor residues $(22,23)$. Moreover, positions 6 and 7 were also involved in binding, because Ala substitution at these positions almost abrogated binding to HLA-A2.1, and more surprisingly, replacement of position 4 and 8 by Ala yielded peptides with a higher binding affinity. Substitutions of $\mathrm{D}$ at position 1 by aromatic and polar residues resulted also in peptides with a higher affinity for HLA-A2.1, in accordance with previous reports $(28,29)$. Some of these peptides with an improvement in their sequence were of great interest in testing in CTL assays, in order to study whether these replacements had increased MHC class I binding without impairing CTL activity.

Substituted peptides were tested in CTL assays, and 1A and 8A showed higher CTL activity than C7A2-WT when tested with a C7A2-WT-specific human CTL line, and both $1 \mathrm{~A}$ and $8 \mathrm{~A}$, together with other peptides with substitutions at position 1, were recognized by C7A2-WT-specific CTL lines raised in HLA-A2.1 AAD transgenic mice. Although all the lines recognized the same epitope, differences in fine specificity between lines may be explained by differences in the TCR specificity. Thus, position 3 is the main epitopic residue in the human line (substitution $3 \mathrm{~A}$ completely abolishes CTL recognition without affecting HLA-A2.1 binding), whereas position 5 is the key epitopic residue in the mouse lines. A possible explanation for the differences in fine specificity between these lines would be that the TCR in the human line contacts the peptide around the $\mathrm{NH}_{2}$-terminal region residues, and therefore, changes at position 1, although they improve peptide binding, may result in conformational changes that affect the peptide-MHC structure recognized by the TCR around position 3. However, mouse TCRs recognized C7A2 around position 5, and replacements at position 1 would improve binding and at the same time did not affect peptide structure for CTL recognition. As a result of these experiments, substitutions at 

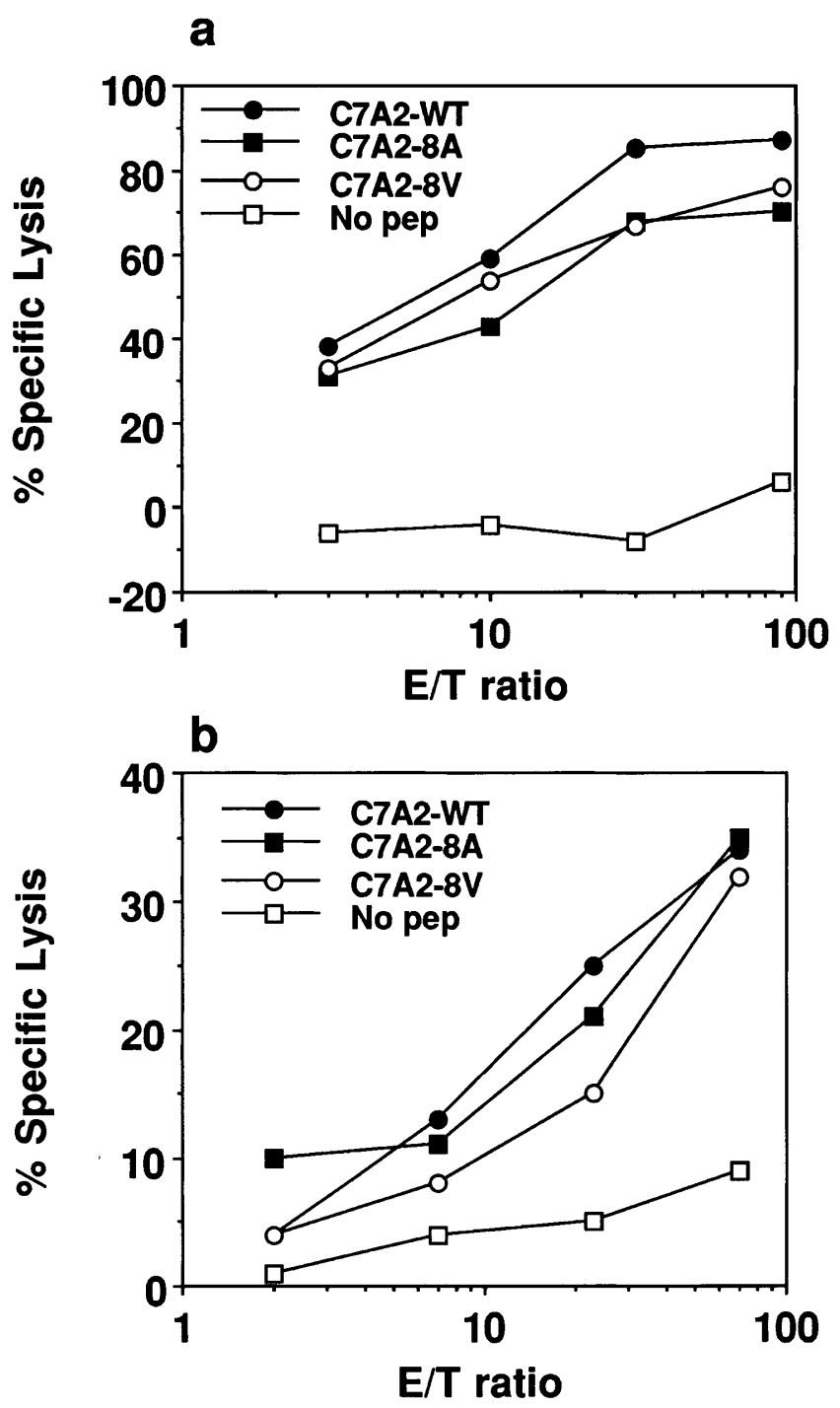

Figure 8. Recognition of C7A2-derived peptides from different $\mathrm{HCV}$ genotypes by CTL induced following immunization with peptide $8 \mathrm{~A}$. (a) AAD and (b) A2Kb transgenic mice were immunized with 50

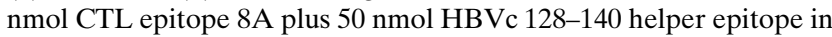
IFA. 2 wk later, they were boosted under the same conditions, and 10$14 \mathrm{~d}$ after the boost, spleen cells were removed and stimulated in vitro with $10 \mu \mathrm{M}$ CTL peptide-pulsed spleen cells. After 2 wk of in vitro stimulation, CTL assay was performed with target cells (Con A blasts) incubated with the different peptides at $10 \mu \mathrm{M}$. C7A2-WT has a sequence from $\mathrm{HCV}$ genotypes $1 \mathrm{a}, 1 \mathrm{~b}$, and $3 \mathrm{a}$, whereas peptide C7A2-8V has a sequence from genotypes $2 \mathrm{a}$ and $2 \mathrm{~b}$.

agretopic residues were more attractive in order to enhance CTL activity, because replacement at these positions would probably not affect interactions between the TCR and the peptide-MHC complex, whereas replacement of epitopic residues might have different effects depending on the characteristic specificity of each particular line.

To use the epitopes as components of a vaccine aimed at enhancing anti-HCV immune response, the activity as in vivo immunogens of some of the peptides previously tested was studied in the AAD HLA-A2.1 transgenic mouse model. This model allows one to test immunogenicity in vivo of peptides presented by human HLA molecules without having to immu- nize humans, and the response in the transgenic mice has been shown to be predictive of that in humans $(9,49)$. Of all the peptides tested, only $8 \mathrm{~A}$ showed a higher immunogenicity than C7A2, whereas peptides with substitutions at position 1 were unable to induce any significant response, although they were recognized by C7A2-specific CTL lines. Together with this high in vivo immunogenicity, recognition of C7A2 by $8 \mathrm{~A}$-specific CTLs was tested, showing that CTL responses against C7A2 were stronger after immunization with $8 \mathrm{~A}$ than the responses induced by C7A2 itself in both HLA-A2.1 AAD and $\mathrm{A} 2 \mathrm{~Kb}$ transgenic mice strains. These results are in agreement with several reports showing a relationship between $\mathrm{MHC}$ class I binding and in vitro $(30,36)$ and in vivo $(30,32,33,58)$ immunogenicity. In all these cases, a high MHC class I binding affinity correlated with the ability to induce a response in immunized animals or to stimulate in vitro cells from virusinfected or cancer patients. We suggest that increased affinity for MHC can enhance in vivo immunogenicity by increasing the density of peptide-MHC complexes on antigen-presenting cells, a property shown to be important for the induction of a CTL response (64).

Another important property of CTL to be induced by a vaccine is high avidity for the target antigen, that is ability to respond to low densities of peptide-MHC complex on the target cell, as we (61) and others (62) have shown that this property is essential for optimal clearance of virus infection in vivo. Therefore, we tested whether the CTL raised by immunization with the 8A peptide killed targets presenting the C7A2-WT peptide at concentrations as low as or lower than those required for killing by CTL raised by immunization with the C7A2-WT peptide itself. Indeed, we found that the CTL raised against $8 \mathrm{~A}$ had substantially higher avidity for the complex of HLA-A2.1 and the C7A2-WT peptide than did the CTL raised against the wild-type peptide. Thus, these CTLs may be qualitatively better than those raised against the wildtype peptide, in addition to being quantitatively greater in numbers. We conclude that the modified peptide $8 \mathrm{~A}$ has at least two advantages as a vaccine, being more immunogenic and inducing higher avidity CTL. Both of these properties should contribute to enhanced efficacy in a vaccine.

Nevertheless, empirical characterization of in vivo immunogenicity of the peptides to be used as immunogens is important, since we found in this study that good MHC class I binding affinity and CTL recognition are not always sufficient to induce a CTL response. Among all the peptides tested, only $8 \mathrm{~A}$ was a good immunogen. The reasons the other peptides were unable to stimulate a primary immune response remain unknown. The most interesting example in this last group is 1A, a peptide with good recognition by both human and mouse CTL but a very poor in vivo immunogen. These results point out the importance of testing the ability of the peptides to induce a good in vivo immune response before they are considered to be included in a vaccine. In our case, the HLA-A2.1 transgenic mouse model has been a valuable system to study this property of the different peptides. Although there may be some differences in fine specificity between human and mouse T cells, substitutions at positions involved in MHC class I binding can avoid affecting TCR recognition, so any change in positions modifying HLA-A2.1 binding are likely to have the same effect both in mouse and human CTL activity.

Together with the higher immunogenicity, recognition of peptides belonging to other viral genotypes by peptide $8 \mathrm{~A}-$ 
induced CTL was another point of importance to vaccine development. $\mathrm{HCV}$ is a virus with a high degree of variation, and several types and subtypes have been defined in different geographical areas (65). C7A2 is an epitope located in a conserved region within the $\mathrm{HCV}$ genome, and the sequence used for the present study is common in viral isolates from genotypes 1a, $1 \mathrm{~b}$, and $3 \mathrm{a}(1,66-68)$. Among all the peptides tested, $8 \mathrm{~V}$ had the sequence of viral isolates from genotypes $2 \mathrm{a}$ and $2 \mathrm{~b}(56$, 57 ), and despite having a mutation at position 8 (as peptide 8A), 8A-induced CTL recognized 8V-pulsed target cells similarly to cells pulsed with C7A2. This recognition may be explained because substitution by $\mathrm{V}$ at position 8 still retains an aliphatic side chain, with an intermediate size between that of L and A, allowing binding to HLA-A2.1 without affecting interactions with the TCR. Recognition of $8 \mathrm{~V}$ was also seen in the case of C7A2-induced CTL. Thus, together with the enhancement of immunogenicity, broad recognition of viral genotype sequences was obtained with 8A-induced CTL.

Enhanced immunogenicity and induction of an immune response with a broad specificity for different viral genotypes make $8 \mathrm{~A}$ a good candidate to be included as a component in a subunit vaccine. It can be included and delivered in a peptide vaccine, as described for HBV infection (69), in a recombinant virus, or in a nucleic acid vaccine with HCV sequences containing the replacements made in the appropriate subunits. This approach of modifying epitopes to enhance their immunogenicity has been succesfully used in different systems, with viral (34) or tumor (35) antigens. This is the first case, to our knowledge, where the improvement of a viral CTL epitope recognized by human cells has been tested both in vitro and in vivo. This epitope enhancement approach could be used also with CD4 T-helper epitopes, as described in other systems (38, 45), and antigens carrying combinations of improved epitopes recognized by different lymphocyte populations could be incorporated in a vaccine designed to enhance the antiviral immune response. Moreover, we have shown peptide $8 \mathrm{~A}$ to be more potent than $\mathrm{C} 7 \mathrm{~A} 2$ in stimulating in vitro the CTL response induced in vivo by viral infection, as in the case of the human CTL line, suggesting that it could also be used in immunotherapy to enhance already existing CTL activity.

In conclusion, replacement of secondary anchor residues in a HLA-A2.1-restricted CTL epitope from a conserved region of the HCV core protein yielded a peptide with enhanced in vitro and in vivo immunogenicity, as tested in human and HLA-A2.1 transgenic mice models. This peptide also induces CTL recognizing sequences from a broad spectrum of viral genotypes. These results suggest that this peptide could be used to induce CTL in vitro for adoptive transfer immunotherapy and as a component in a vaccine aimed at clearing HCV infection. Moreover, the results demonstrate proof of principle of this epitope enhancement strategy, which could also be used for other epitopes in $\mathrm{HCV}$ antigens to enhance antiviral immune response.

\section{Acknowledgments}

We thank Drs. Tatsumi Arichi and Takafumi Saito for help and advice, and Drs. William E. Biddison and David H. Margulies for critical reading of the manuscript and helpful suggestions.

P. Sarobe was supported by a grant from the Fundación Ramón Areces, Spain, and V. Engelhard was supported by Public Health Service grant AI-21393.

\section{References}

1. Choo, Q.-L., G. Kuo, A.J. Weiner, L.R. Overby, D.W. Bradley, and M. Houghton. 1989. Isolation of a cDNA clone derived from blood-borne non-A non-B viral hepatitis genome. Science. 244:359-362.

2. Dienstag, J.L. 1983. Non-A, non-B hepatitis. I. Recognition, epidemiology, and clinical features. Gastroenterology. 85:439-462.

3. Townsend, A., and H. Bodmer. 1989. Antigen recognition by class I-restricted T lymphocytes. Annu. Rev. Immunol. 7:601-624.

4. Kast, W.M., R. Offringa, P.J. Peters, A.C. Voordouw, R.H. Meloen, A.J. van der Eb, and C.J.M. Melief. 1989. Eradication of adenovirus E1-induced tumors by E1A-specific cytotoxic T lymphocytes. Cell. 59:603-614.

5. Kast, W.M., L. Roux, J. Curren, H.J.J. Blom, A.C. Voordouw, R.H. Meloen, D. Kolakofsky, and C.J.M. Melief. 1991. Protection against lethal Sendai virus infection by in vivo priming of virus-specific cytotoxic T lymphocytes with a free synthetic peptide. Proc. Natl. Acad. Sci. USA. 88:2283-2287.

6. Schulz, M., R.M. Zinkernagel, and H. Hengartner. 1991. Peptide-induced antiviral protection by cytotoxic T cells. Proc. Natl. Acad. Sci. USA. 88:991-993.

7. Taylor, P.M., and B.A. Askonas. 1986. Influenza nucleoprotein-specific cytotoxic T-cell clones are protective in vivo. Immunology. 58:417-420.

8. Shirai, M., H. Okada, M. Nishioka, T. Akatsuka, C. Wychowski, R. Houghten, C.D. Pendleton, S.M. Feinstone, and J.A. Berzofsky. 1994. An epitope in hepatitis $\mathrm{C}$ virus core region recognized by cytotoxic $\mathrm{T}$ cells in mice and humans. J. Virol. 68:3334-3342.

9. Shirai, M., T. Arichi, M. Nishioka, T. Nomura, K. Ikeda, K. Kawanishi, V.H. Engelhard, S.M. Feinstone, and J.A. Berzofsky. 1995. CTL responses of HLA-A2.1-transgenic mice specific for hepatitis $\mathrm{C}$ viral peptides predict epitopes for CTL of humans carrying HLA-A2.1. J. Immunol. 154:2733-2742.

10. Cerny, A., J.G. McHutchison, C. Pasquinelli, M.E. Brown, M.A. Brothers, B. Grabscheid, P. Fowler, M. Houghton, and F.V. Chisari. 1995. Cytotoxic $\mathrm{T}$ lymphocyte response to hepatitis $\mathrm{C}$ virus-derived peptides containing the HLA A2.1 binding motif. J. Clin. Invest. 95:521-530.

11. Koziel, M.J., D. Dudley, N. Afdhal, Q.-L. Choo, M. Houghton, R. Ralston, and B.D. Walker. 1993. Hepatitis C virus (HCV)-specific cytotoxic T lymphocytes recognize epitopes in the core and envelope proteins of HCV.J. Virol. 67:7522-7532.

12. Battegay, M., J. Fikes, A.M. Di Bisceglie, P.A. Wentworth, A. Sette, E. Celis, W.-M. Ching, A. Grakoui, C.M. Rice, K. Kurokohchi, et al. 1995. Patients with chronic hepatitis $\mathrm{C}$ have circulating cytotoxic $\mathrm{T}$ cells which recognize hepatitis $\mathrm{C}$ virus-encoded peptides binding to HLA-A2.1 molecules. J. Virol. 69: 2462-2470.

13. Kita, H., T. Moriyama, T. Kaneko, I. Harase, M. Nomura, H. Miura, I. Nakamura, Y. Yazaki, and M. Imawari. 1993. HLA B44-restricted cytotoxic T lymphocytes recognizing an epitope on hepatitis $\mathrm{C}$ virus nucleocapsid protein. Hepatology. 18:1039-1044.

14. Kurokohchi, K., T. Akatsuka, C.D. Pendleton, A. Takamizawa, M Nishioka, M. Battegay, S.M. Feinstone, and J.A. Berzofsky. 1996. Use of recombinant protein to identify a motif-negative human CTL epitope presented by HLA-A2 in the hepatitis C virus NS3 region. J. Virol. 70:232-240.

15. Koziel, M.J., D. Dudley, J.T. Wong, J. Dienstag, M. Houghton, R. Ralston, and B.D. Walker. 1992. Intrahepatic cytotoxic T lymphocytes specific for hepatitis C virus in persons with chronic hepatitis. J. Immunol. 149:3339-3344.

16. Erickson, A.L., M. Houghton, Q.-L. Choo, A.J. Weiner, R. Ralston, E. Muchmore, and C.M. Walker. 1993. Hepatitis C virus-specific responses in the liver of chimpanzees with acute and chronic hepatitis C. J. Immunol. 151:41894199.

17. Rehermann, B., K.M. Chang, J.G. McHutchison, R. Kokka, M. Houghton, and F.V. Chisari. 1996. Quantitative analysis of the peripheral blood cytotoxic $\mathrm{T}$ lymphocyte response in patients with chronic hepatitis $\mathrm{C}$ virus infection. J. Clin. Invest. 98:1432-1440.

18. Chisari, F.V. 1997. Cytotoxic T cells and viral hepatitis. J. Clin. Invest. 99:1472-1477.

19. Townsend, A.R.M., J. Rothbard, F.M. Gotch, G. Bahadur, D. Wraith, and A.J. McMichael. 1986. The epitopes of influenza nucleoprotein recognized by cytotoxic T lymphocytes can be defined with short synthetic peptides. Cell. 44:959-968.

20. Germain, R.N., and D.H. Margulies. 1993. The biochemistry and cell biology of antigen processing and presentation. Annu. Rev. Immunol. 11:403-450.

21. Matsumura, M., D.H. Fremont, P.A. Peterson, and I.A. Wilson. 1992 Emerging principles for the recognition of peptide antigens by MHC class I molecules. Science. 257:927-934.

22. Falk, K., O. Rötzschke, S. Stevanovic, G. Jung, and H.-G. Rammensee. 1991. Allele-specific motifs revealed by sequencing of self-peptides eluted from MHC molecules. Nature. 351:290-296.

23. Hunt, D.F., R.A. Henderson, J. Shabanowitz, K. Sakaguchi, H. Michel, N. Sevilir, A.L. Cox, E. Appella, and V.H. Engelhard. 1992. Characterization of peptides bound to the class I MHC molecule HLA-A2.1 by mass spectrometry. Science. 255:1261-1263.

24. Kast, W.M., R.M.P. Brandt, J. Sidney, J.-W. Drijfhout, R.T. Kubo, H.M. Grey, C.J.M. Melief, and A. Sette. 1994. Role of HLA-A motifs in identification of potential CTL epitopes in human papillomavirus type $16 \mathrm{E} 6$ and E7 proteins. J. Immunol. 152:3904-3912. 
25. Sidney, J., H.M. Grey, S. Southwood, E. Celis, P.A. Wentworth, M.-F. del Guercio, R.T. Kubo, R.W. Chesnut, and A. Sette. 1996. Definition of an HLA-A3-like supermotif demonstrates the overlapping peptide-binding repertoires of common HLA molecules. Hum. Immunol. 45:79-93.

26. Rötzschke, O., and K. Falk. 1991. Naturally-occurring peptide antigens derived from the MHC class-I-restricted processing pathway. Immunol. Today. 12:447-455.

27. Parker, K.C., M.A. Bednarek, L.K. Hull, U. Utz, B. Cunningham, H.J. Zweerink, W.E. Biddison, and J.E. Coligan. 1992. Sequence motifs important for peptide binding to the human MHC class I molecule, HLA-A2. J. Immunol. 149:3580-3587.

28. Ruppert, J., J. Sidney, E. Celis, R.T. Kubo, H.M. Grey, and A. Sette. 1993. Prominent role of secondary anchor residues in peptide binding to HLAA2.1 molecules. Cell. 74:929-937.

29. Parker, D.C., M.A. Bednarek, and J.E. Coligan. 1994. Scheme for ranking potential HLA-A2 binding peptides based on independent binding of individual peptide side-chains. J. Immunol. 152:163-175.

30. Wentworth, P.A., A. Sette, E. Celis, J. Sidney, S. Southwood, C. Crimi, S. Stitely, E. Keogh, N.C. Wong, B. Livingston, et al. 1996. Identification of A2restricted hepatitis $\mathrm{C}$ virus-specific cytotoxic $\mathrm{T}$ lymphocyte epitopes from conserved regions of the viral genome. Int. Immunol. 8:651-659.

31. Gulukota, K., and C. DeLisi. 1996. HLA allele selection for designing peptide vaccines. Genet. Anal. 13:81-86.

32. Lipford, G.B., S. Bauer, H. Wagner, and K. Heeg. 1995. Peptide engineering allows cytotoxic T-cell vaccination against human papilloma virus tumour antigen, E6. Immunology. 84:298-303.

33. Lipford, G.B., S. Bauer, H. Wagner, and K. Heeg. 1995. In vivo CTL induction with point-substituted ovalbumin peptides: immunogenicity correlates with peptide-induced MHC class I stability. Vaccine. 13:313-320.

34. Pogue, R.R., J. Eron, J.A. Frelinger, and M. Matsui. 1995. Amino-terminal alteration of the HLA-A*0201-restricted human immunodeficiency virus pol peptide increases complex stability and in vitro immunogenicity. Proc. Natl. Acad. Sci. USA. 92:8166-8170.

35. Parkhurst, M.R., M.L. Salgaller, S. Southwood, P.F. Robbins, A. Sette, S.A. Rosenberg, and Y. Kawakami. 1996. Improved induction of melanomareactive CTL with peptides from the melanoma antigen gp100 modified at HLA-A*0201-binding residues. J. Immunol. 157:2539-2548.

36. Sette, A., A. Vitiello, B. Reherman, P. Fowler, R. Nayersina, W.M. Kast, C.J.M. Melief, C. Oseroff, L. Yuan, J. Ruppert, et al. 1994. The relationship between class I binding affinity and immunogenicity of potential cytotoxic T cell epitopes. J. Immunol. 153:5586-5592.

37. Wentworth, P.A., A. Vitiello, J. Sidney, E. Keogh, R.W. Chesnut, H. Grey, and A. Sette. 1996. Differences and similarities in the A2.1-restricted cytotoxic $\mathrm{T}$ cell repertoire in humans and human leukocyte and antigen-transgenic mice. Eur. J. Immunol. 26:97-101.

38. Boehncke, W.-H., T. Takeshita, C.D. Pendleton, S. Sadegh-Nasseri, L. Racioppi, R.A. Houghten, J.A. Berzofsky, and R.N. Germain. 1993. The importance of dominant negative effects of amino acids side chain substitution in peptide-MHC molecule interactions and T cell recognition. J. Immunol. 150: 331-341.

39. Altuvia, Y., J.A. Berzofsky, R. Rosenfeld, and H. Margalit. 1994. Sequence features that correlate with MHC restriction. Mol. Immunol. 31:1-19.

40. Mueller, D.L., M.K. Jenkins, and R.H. Schwartz. 1989. Clonal expansion versus functional clonal inactivation: a costimulatory signalling pathway determines the outcome of T cell antigen receptor occupancy. Annu. Rev. Immunol. 7:445-480.

41. Weaver, C.T., and E.R. Unanue. 1990. The costimulatory function of antigen-presenting cells. Immunol. Today. 11:49-55.

42. Berzofsky, J.A. 1993. Epitope selection and design of synthetic vaccines: molecular approaches to enhancing immunogenicity and cross-reactivity of engineered vaccines. Ann. NY Acad. Sci. 690:256-264.

43. Berzofsky, J.A. 1995. Designing peptide vaccines to broaden recognition and enhance potency. Ann. NY Acad. Sci. 754:161-168.

44. Berzofsky, J.A., and I.J. Berkower. 1995. Novel approaches to peptide and engineered protein vaccines for HIV using defined epitopes: advances in 1994-95. AIDS. 9(Suppl. A):S143-S157.

45. Ahlers, J.D., T. Takeshita, C.D. Pendleton, and J.A. Berzofsky. 1997. Enhanced immunogenicity of HIV-1 vaccine construct by modification of the native peptide sequence. Proc. Natl. Acad. Sci. USA. 94:10856-10861.

46. Paterson, A.C., R. Sciot, M.C. Kew, F. Callea, G.M. Dusheiko, and V.J. Desmet. 1988. HLA expression in human hepatocellular carcinoma. Br. J. Cancer. 57:369-373.

47. Vitiello, A., D. Marchesini, J. Furze, L.A. Sherman, and R.W. Chesnut. 1991. Analysis of the HLA-restricted influenza-specific cytotoxic T lymphocyte response in transgenic mice carrying a chimeric human-mouse class I major histocompatibility complex. J. Exp. Med. 173:1007-1015.

48. Newberg, M.H., D.H. Smith, D.R. Vining, E. Lacy, and V.H. Engelhard. 1996. Importance of MHC class I $\alpha 2$ and $\alpha 3$ domains in the recognition of self and non-self MHC molecules. J. Immunol. 156:2473-2480.

49. Man, S., M.H. Newberg, V.L. Crotzer, C.J. Luckey, N.S. Williams, Y. Chen, E.L. Huczko, J.P. Ridge, and V.H. Engelhard. 1995. Definition of a human $\mathrm{T}$ cell epitope from influenza A non-structural protein 1 using HLA-A2.1 transgenic mice. Int. Immunol. 7:597-605.

50. Salter, R.D., D.N. Howell, and P. Cresswell. 1985. Genes regulating HLA class I antigen expression in T-B lymphoblast hybrids. Immunogenetics. 21:235-246.

51. Spies, T., and R. DeMars. 1991. Restored expression of major histocompatibility class I molecules by gene transfer of a putative peptide transporter. Nature. 351:323-324.

52. Irwin, M.J., W.R. Heath, and L.A. Sherman. 1989. Species-restricted interactions between CD 8 and the $\alpha 3$ domain of class I influence the magnitude of the xenogeneic response. J. Exp. Med. 170:1091-1101.

53. Nijman, H.W., J.G.A. Houbiers, M.P.M. Vierboom, S.H. van der Burg, J.W. Drijfhout, J. D'Amaro, P. Kenemans, C.J.M. Melief, and W.M. Kast. 1993. Identification of peptide sequences that potentially trigger HLA-A2.1restricted cytotoxic T lymphocytes. Eur. J. Immunol. 23:1215-1219.

54. Ahlers, J.D., N. Dunlop, D.W. Alling, P.L. Nara, and J.A. Berzofsky. 1997. Cytokine-in-adjuvant steering of the immune response phenotype to HIV-1 vaccine constructs: GM-CSF and TNF $\alpha$ synergize with IL-12 to enhance induction of CTL. J. Immunol. 158:3947-3958.

55. Cerny, A., P. Fowler, M.A. Brothers, M. Houghton, H.J. Schlicht, and F.V. Chisari. 1995. Induction in vitro of a primary human antiviral cytotoxic T cell response. Eur. J. Immunol. 25:627-630.

56. Okamoto, H., S. Okada, Y. Sugiyama, K. Kurai, H. Iizuka, A. Machida, Y. Miyakawa, and M. Mayumi. 1991. Nucleotide sequence of the genomic RNA of hepatitis $\mathrm{C}$ virus isolated from a human carrier: comparison with reported isolates for conserved and divergent regions. J. Gen. Virol. 72:2697-2704.

57. Okamoto, H., K. Kurai, S.-I. Okada, K. Yamamoto, H. Lizuka, T. Tanaka, S. Fukuda, F. Tsuda, and S. Mishiro. 1992. Full-length sequence of a hepatitis $\mathrm{C}$ virus genome having poor homology to reported isolates: comparative study of four distinct genotypes. Virology. 188:331-341.

58. Ressing, M.E., A. Sette, R.M.P. Brandt, J. Ruppert, P.A. Wentworth, M. Hartman, C. Oseroff, H.M. Grey, C.J.M. Melief, and W.M. Kast. 1995. Human CTL epitopes encoded by human papillomavirus type 16 E6 and E7 identified through in vivo and in vitro immunogenicity studies of HLA-A*0201-binding peptides. J. Immunol. 154:5934-5943.

59. Engelhard, V.H., E. Lacy, and J.P. Ridge. 1991. Influenza A-specific, HLA-A2.1-restricted cytotoxic T lymphocytes from HLA-A2.1 transgenic mice recognize fragments of the M1 protein. J. Immunol. 146:1226-1232.

60. Newberg, M.H., J.P. Ridge, D.R. Vining, R.D. Salter, and V.H. Engelhard. 1992. Species specificity in the interaction of CD8 with the a3 domain of MHC class I molecules. J. Immunol. 149:136-142.

61. Alexander-Miller, M.A., G.R. Leggatt, and J.A. Berzofsky. 1996. Selective expansion of high or low avidity cytotoxic $\mathrm{T}$ lymphocytes and efficacy for adoptive immunotherapy. Proc. Natl. Acad. Sci. USA. 93:4102-4107.

62. Gallimore, A., T. Dumrese, H. Hengartner, R.M. Zinkernagel, and H.G. Rammensee. 1998. Protective immunity does not correlate with the hierarchy of virus-specific cytotoxic $\mathrm{T}$ cell responses to naturally processed peptides. J. Exp. Med. 187:1647-1657.

63. Takahashi, H., Y. Nakagawa, C.D. Pendleton, R.A. Houghten, K. Yokomuro, R.N. Germain, and J.A. Berzofsky. 1992. Induction of broadly cross-reactive cytotoxic T cells recognizing an HIV-1 envelope determinant. Science. 255:333-336.

64. Alexander, M.A., C.A. Damico, K.M. Wieties, T.H. Hansen, and J.M. Connolly. 1991. Correlation between CD8 dependency and determinant density using peptide-induced, $\mathrm{L}^{\mathrm{d}}$-restricted cytotoxic T lymphocytes. J. Exp. Med. 173:849-858.

65. Simmonds, P., E.C. Holmes, T.-A. Cha, S.-W. Chan, F. McOmish, B. Irvine, E. Beall, P.L. Yap, J. Kolberg, and M.S. Urdea. 1993. Classification of hepatitis $\mathrm{C}$ virus into six major genotypes and a series of subtypes by phylogenetic analysis of the NS-5 region. J. Gen. Virol. 74:2391-2399.

66. Ogata, N., H.J. Alter, R.H. Miller, and R.H. Purcell. 1991. Nucleotide sequence and mutation rate of the $\mathrm{H}$ strain of hepatitis $\mathrm{C}$ virus. Proc. Natl. Acad. Sci. USA. 88:3392-3396.

67. Kato, N., M. Hijikata, Y. Ootsuyama, M. Nakagawa, S. Ohkoshi, T. Sugimura, and K. Shimotohno. 1990. Molecular cloning of the human hepatitis C virus genome from Japanese patients with non-A, non-B hepatitis. Proc. Natl Acad. Sci. USA. 87:9524-9528.

68. Sakamoto, M., Y. Akahane, F. Tsuda, T. Tanaka, D.G. Woodfield, and H. Okamoto. 1994. Entire nucleotide sequence and characterization of a hepatitis C virus genotype V/3a. J. Gen. Virol. 75:1761-1768.

69. Vitiello, A., G. Ishioka, H.M. Grey, R. Rose, P. Farness, R. LaFond, L. Yuan, F.V. Chisari, J. Furze, R. Bartholomeuz, et al. 1995. Development of a lipopeptide-based therapeutic vaccine to treat chronic HBV infection. I. Induc tion of a primary cytotoxic T lymphocyte response in humans. J. Clin. Invest. 95: 341-349. 